\title{
Specifying textiles in a greener world: using sustainable strategies to develop new criteria
}

\author{
J. Stark \\ College of Visual Arts \& Design, University of North Texas, USA
}

\begin{abstract}
The complexity of specifying textiles for environmentally-conscious commercial interiors has evolved as layers of evaluative criteria have been added. Increases in information require that designers understand more about textile design and manufacture, and use new processes for product selection.

Textiles are the focus of this investigation for several reasons. They are an integral architectural and interior design element and embody an array of art, craft, design, and technology. Historically, the textile industry has been the source of environmental transgressions contributing to pollution on many levels. These characteristics are shared with other interior products, so new paradigms can generalize to other materials. The evolution of the textile industry is also the centerpiece for one of the most significant proposals targeting green product design, the "cradle-to-cradle" philosophy developed by William McDonough and Michael Braungart. Finally, the commercial project emphasis is appropriate because products for this market are subject to rigorous review for compliance with regulatory and performance standards.

Based on a review of sources from interior design education and practice, this study will identify and analyze the development of textile specification criteria for environmentally-conscious commercial textiles. This investigation occurs in the context of a burgeoning awareness of green products and suggests that new specification approaches are needed. Although any discussion of commercial textiles has global implications, this report primarily addresses interior design practice in the United States.
\end{abstract}

Keywords: interior design, design education, commercial textiles, sustainability, life cycle assessment. 


\section{Introduction}

The evolution of textile specification in interior design practice is reflected in interior design instruction. In traditional introductory texts such as Interior Design \& Decoration, [2], textile selection is based on historical period stylistic elements including color, pattern, texture, and fiber content. Quality is addressed through an understanding of craftsmanship and appropriateness for use, which was primarily residential until the early twentieth century when interior stylists expanded the practice to include public venues. As new building and construction technologies made high-rise, high-occupancy office buildings possible, commercial interiors developed as a design specialty. Noting that there were "few suitable fabrics available in the postwar period" to complement the advanced designs of the Knoll furniture line, Florence Knoll Bassett founded KnollTextiles in 1947, which united commercial furniture and fabric production [3]. Jack Lenor Larsen established his high design international textile studio in 1952, and his Fabrics for Interiors [4] has been a touchstone for understanding weave structures and fiber characteristics.

In addition to aesthetics, health and life safety became critical issues in the context of commercial projects. Throughout the twentieth century, textile products were scrutinized for content and performance. Some of the first regulations had to do with fiber content labeling. The Federal Trade Commission (FTC) was created by the U.S. Congress in 1914, and reinforced by the WheelerLea Act of 1938 which included guidelines for textile labeling and marketing [5]. The Wool Products Labeling Act of 1939 stipulated definitions of wool, recycled wool, and virgin wool, the registered FTC number and the country of origin [5]. The Textile Fiber Products Identification Act of 1960 required fiber type, percentage, manufacturer's name, and country of origin. Code regulation was the response for disasters in public spaces, e.g., the Cocoanut Grove nightclub fire in Boston, 1942, and, in addition to addressing fire exits, mandated "more stringent requirements for decorations" [6]. The Flammable Fabrics Act of 1953 banned the sale of flammable garments and was amended in 1967 to ban the manufacture of flammable goods [6]. The Steiner Tunnel Test (1922) is the oldest interior finish test. In 1968, it was expanded to include recommendations "for adhesives, foams, wallcoverings, and heavy textiles" [6].

Labeling fabrics for commercial use required inclusion of performance criteria. The Association for Contract Textiles (ACT, 1985), "a not-for-profit trade association," [7] standardized categories and baselines for evaluative data. ACT Guidelines include standards for flame resistance, crocking, colorfastness, physical properties and durability. Currently, there are over 40 member entities including textile wholesalers, furniture manufacturers and suppliers, all engaged in a global distribution network. Specifying Commercial Interiors (1989) [8], and The Codes Guidebook for Interiors (1994, revised 2005) [9], were significant specialized texts which provided detailed information for textile specification based on commercial regulations and performance criteria. Designers were introduced to standards developed by the American Society for Testing and Materials (ASTM, 1898), and standards coordinated by the American National Standards Institute (ANSI, 1918). 


\section{Methodology}

This study utilizes a qualitative research strategy supported by topical inventories, chronologies, and supporting documentation to trace the development of regulations, standards, certifications and guidelines pertaining to environmentally-conscious textile specification. Concurrent with the progress in textile production and evaluation, is the effort by design educators and practitioners to assimilate this data and use it to inform design decisions. The intent of the study is to provide an overview of the layers of information that are now available for establishing textile criteria and propose new approaches to strengthen specification processes.

\section{Discussion}

By the end of the twentieth century, dramatic changes in technology, regulatory policy and global economics had transformed the character of textile products for interior environments. Textile manufacture would also be affected by another phenomenon in progress. As described by the Building Design \& Construction authors in their "White Paper on Sustainability: A Report on the Green Building Movement," [10], events in the United States including the publication of Silent Spring by Rachel Carson in 1962 and the 1973 OPEC oil embargo had raised expectations for high performance and healthful built environments. The immediacy of the energy crisis subsided, but technological advances in the design of more effective building systems and materials were underway.

\subsection{Green textile development}

In 1993, Susan Lyons of Designtex invited architect William McDonough to collaborate on the development of a green textile line. William McDonough had been interested in environmentally and socially responsible design since the 1970 's, and in 1984, his firm was commissioned "to design the offices of the Environmental Defense Fund, the first of the so-called green offices" [11]. Indoor air quality was an important environmental issue, but identifying finish materials with low emissions of volatile organic compounds (VOCs) was difficult because manufacturers considered product information proprietary. McDonough persevered, and in 1991, with environmental chemist, Michael Braungart, coauthored The Hannover Principles, design guidelines for the 2000 World's Fair, and presented them at the Earth Summit in 1992 [12]. "Foremost among them was 'Eliminate the concept of waste' - not reduce, minimize, or avoid waste. . .but eliminate the very concept, by design" [12].

For William McDonough, [1], textile manufacture was the crucible for the Industrial Revolution, and a metaphor for all that was amiss in production processes. Beginning in England, the once agriculturally-based, craft-centered, cottage industry was transformed into a global enterprise through a series of technological developments in mass production. The green textile project was an opportunity for a revolutionary new approach to product design through a 
thorough analysis of product life cycle stages, or all activities from harvesting raw material through product disposal. The partnership also included McDonough's associate, Michael Braungart, and Rohner Textile AG (Heerbrugg, Switzerland). The result was the development of the Climatex ${ }^{\mathbb{B}}$ fiber system, originally wool and ramie. Extensive testing was done to identify levels of toxicity in the raw wool fiber, in processes used to clean the fiber, and to isolate suitable dyeing compounds. Of the sixty chemical companies invited to participate, all declined except CIBA-Geigy, and "of the 1600 dye formulas that were tested, only 16 were deemed free of toxins, carcinogens, and heavy metals and, therefore, safe to use" [13]. All processes were redesigned, water flow from the factory was potable, and the post-industrial fiber waste was used as mulch.

The Climatex ${ }^{\circledR}$ project embodied McDonough's vision for the Next Industrial Revolution and defined his concepts of "waste equals food," "cradle-to-cradle," "eco-effectiveness," and product categories of "biological or organic nutrients" and "technical nutrients" [1]. McDonough took the notion of the cradle-to-grave product life cycle analysis and closed the loop. His ideas stressed that product design control is essential if the "waste equals food" cycle is to be maintained. McDonough's project linked the life cycle approach to textile manufacture and established a quantitative logic in defining sustainable textile attributes: renewable, recycled or recyclable raw materials and non-polluting processes.

\subsection{Life cycle analysis}

The first significant specification resource in the United States for comprehensive life cycle assessment of building products was the Environmental Resource Guide (ERG), [14], first published in 1992 (revised in 1996) by the American Institute of Architects with funding from the U.S. Environmental Protection Agency (USEPA). The ERG compiled quantitative data based on recognized industry metrics on the environmental impact of building materials and presented the documentation in Construction Specifications Institute (CSI) MasterFormat ${ }^{\mathrm{TM}}$ divisions. Also published in 1992, Environmental by Design, [15], profiled individual finish and furnishings products. The authors developed icons recognizing life cycle categories of production, packing/shipping, installation, use, resource recovery, and other programs such as fair business practices and research and education [15]. Both were printed, static formats.

Other general guides that include textile products are the McGraw-Hill Construction Sweets Network ${ }^{\circledR}$ [16] and the GreenSpec ${ }^{\circledR}$ Directory [17]. Both utilize the CSI MasterFormat ${ }^{\mathrm{TM}}$ system and have online capabilities. The McGraw-Hill source provides a green database of manufacturers' information, but does not stipulate a green "definition." The GreenSpec ${ }^{\circledR}$ Directory is published by Building Green Inc., along with Environmental Building News ${ }^{\mathrm{TM}}$, a monthly newsletter, and Building Green Suite, an online resource, all of which do not use advertising or sponsorships. The Building Green staff solicits and evaluates products based on a set of criteria. The categories for consideration of a sustainable textile include products with salvaged, recycled, or agricultural waste content, that conserve natural resources, avoid toxic or other emissions, and contribute to a safe, healthy built environment [17]. 
These guides focus on educating the designer about life cycle categories, increasing the transparency of processes, and presenting product data, not ranking one product over another or evaluating a product in the context of a building program. Further efforts were in progress beginning in the mid-1980's to unify sustainability concerns in whole building design. The U.S. Green Building Council (USGBC), a coalition of professionals from the building design and construction professions, developed the Leadership in Energy and Environmental Design (LEED ${ }^{\mathrm{TM}}$ ) rating system [18]. In 1998, the USGBC approved LEED Version 1.0, and after revisions during a subsequent pilot review, LEED 2.0 for New Construction was approved in March 2000. Projects are evaluated in terms of siting, water and energy use conservation and efficiency, materials sourcing, and indoor environmental quality (IEQ). Points are awarded per category as baseline criteria derived from referenced standards and life cycle data are met. "Although LEED is not without its imperfections, its simple structure, based on achieving points, has given it enormous appeal and made it the most widely accepted program of its kind in the U.S." [10]. Other building programs include Green Globes, Green Guide for Healthcare, and The Collaborative for High Performance Schools (CHPS) [19].

\subsection{Product sourcing and evaluation}

A commitment to specifying sustainable products requires an understanding of the life cycle approach as evidenced by environmentally-conscious attributes. The current market is characterized by a broader selection of green products in conjunction with an increase in third-party product certifications, standards, and guidelines. Third party evaluations are characterized by quantitative testing data and established metrics, provided by an entity with no financial tie to the product. Impartiality, accuracy and consistency determine their worth.

Without the certifications, designers would need to review each individual product and manufacturer's claims, and as Penny Bonda points out, they provide the best defense against "greenwashing" or false or exaggerated marketing claims [19]. On the other hand, challenges exist because there is no clear consensus on what defines a "green" product, certifications measure different attributes, and certifications vary in degree of objectivity.

\subsection{Textile standards}

The concepts developed during the Climatex ${ }^{\circledR}$ project form the basis for the McDonough Braungart Design Chemistry (MBDC) protocol [20]. The protocol was implemented in 2001 and offers product certification in ascending levels of optimization from Preferable to Fully Eco-Effective.

The Institute for Market Transformation to Sustainability (MTS) has developed the SMaRT@ Sustainable Textile Standard 2.0 for Fabric \& Apparel (2004) [21]. The MTS consensus-driven process is certified by ANSI. The group utilizes the triple bottom line model which considers the environment, the economy, and socially responsible practices. The taskforce included stakeholders from architectural firms, the fiber industry, furniture companies, professional 
design organizations, educators, and policy makers. Decisions are framed by established protocols such as the USGBC LEED ${ }^{\text {TM }}$ Rating System, and the Life Cycle Assessment (LCA) International Organization for Standardization (ISO) General Principles Standard [21].

In 2005, ACT began working with GreenBlue (founded in 2002), a non-profit institute, NSF International, The Public Health and Safety Company ${ }^{\mathrm{TM}}$ and EPA representatives to develop an ANSI-certified sustainable textile standard [22]. GreenBlue's beginnings were based on projects from MBDC, and uses Cradle to Cradle as its model. The task group has initiated a pilot program and is scheduled to meet Fall 2007 to accept comments and finalize a release date [23].

Another important third party certification for textiles is issued by the Greenguard Environmental Institute (GEI). Air Quality Sciences, an independent product testing lab for indoor air quality, founded Greenguard in 2001, "as the world's first voluntary nationally certified labeling program" [24]. GEI requires independent testing for pollutants only, not a life cycle analysis. Due to the high costs to companies generated by the time and money required for testing, the number of products on the Greenguard Product Guide remained low until the pilot program for LEED $^{\circledR}$ CI (Commercial Interiors), launched in 2002, designated Greenguard as the indoor air quality (IAQ) standard [24].

Finally, Scientific Certification Systems (SCS, 1984) includes wallcoverings in its product reviews and certifies recycled, reclaimed, salvaged, and bio-based materials. SCS is known for unbiased, scientifically-sound evaluations of both individual products and comprehensive certifications such as Environmentally Preferable Products and Services (EPP), a federal purchasing program [19].

\subsection{Global trends}

In response to a global market, product assessment tools are becoming more comprehensive and more transparent. Certification programs increasingly reference the International Organization for Standardization (ISO, 1947) [25]. The ISO is a non-governmental organization that develops voluntary standards for industries and governments. ISO 14000 addresses "environmental management" and "what the organization does to minimize harmful effects on the environment caused by its activities, and to continually improve its environmental performance" [26]. The 2002 World Summit on Sustainable Development in Johannesburg espoused the Life Cycle Initiative and stated that "the concept of Life Cycle Thinking integrates existing consumption and production strategies, preventing a piece-meal approach" [27]. The baseline tools for the new generation of Life Cycle Assessments (LCAs) are ISO 14044 and ISO 14025 which offer a complete profile "that tells you how a product, as the sum of all its processes, harms or supports the global ecosystem" [27]. The analysis is supported by EPA-developed software and reported in terms of 12 environmental impact categories [27]. Deborah Dunning, CEO of The Green ${ }^{\mathrm{TM}}$ Standard.org stresses the urgency in this task since “. . . any product sold in EU countries beginning January 1, 2009, will be required to have a verified Environmental Product Declaration (EPD) based on a product LCA" [27]. 
The development of a Global Product Information System is in progress. The goal is to include Sustainable Product Standards (e.g., MTS SMaRTC Sustainable Standard for Textiles), EPDs, and full version LCAs as assessment tools that are meant to be used in combination [27]. The Green ${ }^{\mathrm{TM}}$ Standard.org has also developed a criteria matrix against which building professionals can review certification programs. The categories include the standard development process, transparency and scope of criteria, and auditing and certification [28].

\subsection{More green in interior design education}

As previously discussed, much had changed in textile production and the green building movement by the beginning of the $21^{\text {st }}$ century. In interior design education, survey texts were revised to include sections on sustainable design $[29,30]$. Textbooks specializing in sustainable design are becoming more common [19][26]. Books for textile courses provide guidelines for sustainable attributes and third party certifications $[5,6]$. Some are expanding the discussion of individual products to include a materials philosophy that is more minimal and takes a more holistic view $[5,6,19,26,29,30]$. In 2006, the Interior Design Educators Council (IDEC) issued guidelines for teaching sustainable design [31]. The authors identified the reduction of waste as the foundational principle of sustainability with life cycle assessment as a supporting strategy. They directed designers to take responsibility for sustainable design and approach projects holistically [31].

\section{Limitations}

This report has followed the development and intersection of three thematic strands including textile production for commercial interiors, the green building movement in the United States, and the response by the interior design discipline to new specification paradigms. The study was by no means exhaustive in the inclusion of all information pertinent to textile specifications, and additional investigations should be done on new standards currently in development.

\section{Conclusions}

Based on the review of textile production and third-party certifications, a life cycle approach is crucial in the selection of green textiles. However, complex supply chains make it difficult to track raw material sources and production processes. Even if the original manufacturer has been conscientious, the integrity of the textile can be compromised by the application of toxic finishes, adhesives or cleaning compounds. Other complications arise since commercial textiles are typically installed as a component in an assembly such as a chair or acoustical wall panel. Since much of the process is beyond an individual's control, the designer must rely on information from product designers, manufacturers, fabricators, and those responsible for product maintenance and disposal. Recommendations for dealing with these challenges include expanding the scope 
of the product selection process, learning about attributes unique to textiles, and embracing new technologies for product design and research.

Expanding the scope can be addressed by asking more questions, asking bigger questions, and asking them sooner. Suzanne Drake, with Ashen + Allen, comments on a Metropolis article discussing PVC building products:

These days it is no longer sufficient to ask if a material is safe or legal. To be truly green we need to ask, Is it necessary? Is it necessary that wall-covering be used at all? If the answer is yes, then ask, Is it necessary that the wall-covering last more than 100 years for a client who has only 5-year lease? [32]

In addition to the traditional product questions of "Is the look right? Will it do the job? Does it fit in the budget?", Nadav Malin, Environmental Building News editor, encourages designers to inquire: "Where did it come from? What went into making it? Where can it go when it's no longer needed in my project? Can it be used safely to make something else?" Malin also adds questions on indoor environmental quality, energy use, off-gassing, toxicity, and cleanability [19].

Concurrent with resolving questions about the project scope, the designer establishes appropriate criteria. With all commercial projects, code and regulatory issues come first. Detailed understanding of textile design, production and fabrication methods is a prerequisite for determining performance and aesthetic characteristics as well as green attributes. Product categories from programs such as LEED $^{\text {TM }}$ can also be used to assist in identifying environmental attributes and defining the universe of acceptable products.

In his essay Four Steps to Greening Your Specifications, former CSI president Ross Spiegel recommends developing an evaluative matrix once product categories and attributes are determined [19]. His comments are in the context of preparing project manual specifications for products and materials including physical characteristics, performance, installation, and provision for disposal if applicable. Whether writing their own specifications or working with a specifications writer, designers are urged to begin this process as early as possible in the project, preferably in the schematics phase. The evaluative matrix format is useful for organizing information collected on specific products within a designated category. Information can include testing data, standards, manufacturers' responses to life cycle questions, and third-party certifications. The evaluation becomes the basis for the specification and a source for documentation to support environmental claims.

Comprehensive LCAs are complex and as previously discussed, new software technologies continue to develop to perform these calculations. As Winchip notes, "generally, an interior designer would not personally utilize these programs; however, an awareness. . . can be useful when working with other professionals. .." [26]. The designer may be required to communicate with product designers, engineers, or economists and can embrace life cycle thinking conceptually if not quantitatively. It is also the designer's responsibility to navigate the labyrinth of manufacturers' claims and third-party certifications. New tools are being developed that will allow designers to evaluate the evaluators to ensure objectivity and transparency.

The final recommendation encourages designers to look to new technologies for product sources and research tools. Information can be difficult to access or 
assimilate due to a variety of formats. The use of interactive media can maximize the research exercise since many agencies, guidelines and standards link to each other. Expanding the project view requires designers to analyze information three-dimensionally. Commitment to life cycle thinking adds the fourth dimension, considering products and projects through time.

The area of product standards and certification has been characterized by rapid change and increased complexity. Designers must stay informed and prepared for increased regulations, more rigorous green building certification requirements, and more stringent international project documentation.

Adhering to sustainable principles in textile specification requires a holistic approach and informed discernment in evaluating data from multiple and often disparate sources. Designers can infuse new approaches and content into the design process. Sustainable design as a concept unifies the specification task by addressing aesthetics, performance, cost, health, and environmental issues.

\section{References}

[1] McDonough, W. \& Braungart, M., Cradle to Cradle: Remaking the Way We Make Things, North Point Press: New York, pp. 17-21; 191-204, 2002.

[2] Abercrombie, S. \& Whiton, S., Interior Design \& Decoration, $6^{\text {th }}$ ed., Prentice Education: Upper Saddle River, New Jersey, 2007.

[3] Knoll: News - KnollTextiles: 60 years of design history, June 10, 2007, www.knoll.com/news/vstory

[4] Larsen, J.L. \& Weeks, J., Fabrics for Interiors: a Guide for Architects, Designers, and Consumers, John Wiley \& Sons: New York, 1975.

[5] Nielson, K.J., Interior Textiles: Fabrics, Applications, \& Historical Styles, John Wiley \& Sons: Hoboken, New Jersey, p. 132, 2007.

[6] McGowan, M., Specifying Interiors: a Guide to Construction and FF\&E for Residential and Commercial Interiors Projects, $2^{\text {nd }} e d$. John Wiley \& Sons: Hoboken, New Jersey, pp. 45-47, 2006.

[7] Association for Contract Textiles, www.contract-textiles.com

[8] Reznifoff, S.C., Specifications for Commercial Interiors: Professional Liabilities, Regulations, and Performance Criteria, rev. ed., Whitney Library of Design: New York, 1989.

[9] Harmon, S.K. \& Kennon, K.E., The Codes Guidebook for Interiors, $3^{\text {rd }}$ ed., John Wiley \& Sons: Hoboken, New Jersey, 2005.

[10] Cassidy, R., (ed)., White paper on sustainability: A report on the green building movement. Building Design \& Construction, November, pp. 1-47, 2003, www.bdcmag.com

[11] McDonough, W. \& Braungart, M., Cradle to Cradle: Remaking the Way We Make Things, North Point Press: New York, p. 8, 2002.

[12] McDonough, W. \& Braungart, M., Cradle to Cradle: Remaking the Way We Make Things, North Point Press: New York, p. 15, 2002.

[13] Bonda, P., How green is my textile? IS magazine, 9[6], pp. 20-25, 2002.

[14] Demkin, J., (ed). Environmental Resource Guide, John Wiley \& Sons: New York, 1996. 
[15] Leclair, K. \& Rousseau, D., Environmental by Design: a Sourcebook of Environmentally Conscious Choices for Homeowners, Builders \& Designers, Volume I: Interiors, Hartley \& Marks: Point Roberts, Washington, 1992.

[16] McGraw-Hill Construction, Sweets Network ${ }^{\circledR}$, www.construction.com

[17] Wilson, A., Malin, N. \& Peipkorn, M., (eds). Greenspec ${ }^{\circledR}$ Directory: Product Listings \& Guideline Specifications, $7^{\text {th }}$ edition. BuildingGreen, Inc.: Brattleboro, Vermont, 2007.

[18] U.S. Green Building Council. The LEED ${ }^{\mathrm{TM}}$ Green Building Rating System, www.usgbc.org/LEED

[19] Bonda, P. \& Sosnowchik, K., Sustainable Commercial Interiors, John Wiley \& Sons: Hoboken, New Jersey, pp. 98; 189-204, 2007.

[20] McDonough Braungart Design Chemistry, www.MBDC.org

[21] The Institute for Market Transformation to Sustainability, http://MTS.sustainableproducts.com

[22] GreenBlue, www.greenblue.org

[23] Beautyman, M., Sustainable textile standard on the horizon, Interior Design Newswire, May 24, 2007, www.interiordesign.net

[24] Bonda, P., Product certifications: Clear as mud, ISDesignet, October, pp. 1-4, 2003, www.isdesignet.com/ME2/Audiences/Segments/Publications

[25] International Organization of Standardization, www.iso.org

[26] Winchip, S.M., Sustainable Design for Interior Environments, Fairchild Publications: New York, pp. 59, 98, 2007.

[27] Dunning, D. \& Zander, R., Cover story: a vision of regeneration through sustainable product design and selection, The GreenGuide to NeoCon 2007, Interiors \& Sources Supplement, pp. 16-37, 2007.

[28] Dunning, D. \& Zander, R., The GreenGuide EcoLibrary ${ }^{\mathrm{TM}}$, The Green Guide to NeoCon 2007,, Interiors \& Sources Supplement, pp. 38-42, 2007.

[29] Nielson, K.J. \& Taylor, D.A., Interiors: An Introduction, $2^{\text {nd }}$ ed., Wm. C. Brown Communications: Dubuque, Iowa, 1994.

[30] Pile, J.F., Interior Design, $4^{\text {th }}$ ed., John Wiley \& Sons: Upper Saddle River, New Jersey, 2007.

[31] Stewart-Pollock, J. \& Pillote, L.E., Preliminary teaching manual for sustainable design education, Interior Design Educators Council, 2006, www.idec.org/resource/SDT_Manual.pdf.

[32] Szenasy, S.,(ed)., Dialogue: The vinyl debate, Metropolis, 27[6], p. 22, 2008. 